\title{
Substantive Communication in Organizations, Environment, and Post-Bureaucracy: The Institutionalization of Dialogue and Trust
}

\author{
PhD. Isabella Francisca Freitas Gouveia de Vasconcelos ${ }^{1}$ \\ PhD. HÉlio ARThur Reis IrIgaray ${ }^{1}$ \\ ${ }^{1}$ Fundação Getulio Vargas / Escola Brasileira de Administração Pública e de EMPresas, Rio de Janeiro - RJ, Brazil
}

Nobel prize winner in Economics, Jean Tirole (2018), analyzes progress on environmental protection and the imperative need to maintain global warming to a maximum of 1.5 degrees Celsius. The 2017 Paris Agreement signed by more than 196 countries was a success in this regard, setting ambitious goals to make this a reality. Emerging countries are particularly required to control greenhouse gas emissions, and countries have set targets to minimize their impact.

According to Tirole (2018), the goals must be clear. He proposes clear limits per country for carbon emission; audits to verify whether countries are meeting their targets; taxing carbon emission (Sweden was one of the first countries to introduce such a tax); establishing a universal price regarding emissions.

\section{The Paris Agreement proposes net zero greenhouse gas emission by 2050}

Beyond the immediate and self-serving political logic, the Paris Agreement is a successful example of Habermasian communication, setting goals based on science and facts. It is possible to attribute this success to the government of Emmanuel Macron.

In his book "Economics of the Common Good," Jean Tirole (2018) corroborates the worldwide warning about the need to end gas emissions by 2050. The Paris Agreement estimates that US\$100 billion per year must be distributed to developing countries to achieve this goal, financing activities to reduce emission meeting the countries' targets, green audits, and the implementation of taxes on greenhouse gas emissions.

The development of innovative measures and the continuity of a clear communication demand a dialogue guided, above all, by the interests of the planet, the protection of the environment, peoples' quality of life, and social justice. Also, it is crucial to put into practice the decisions-made throughout this conversation, which confirms its Habermasian inspiration marked by a pragmatic and democratic ethical communication.

Thus, at the 21st UNFCCC Conference of the Parties (COP21) in Paris, a new agreement was adopted with the main goal of strengthening the global response to the threat of climate change and enhancing the countries' ability to deal with the impacts of this change.

\section{Brazil's Nationally Determined Contribution (NDC) in the Paris Agreement}

According to data from the Brazilian Secretariat of the Environment, after approval by the National Congress, Brazil concluded the process of ratification of the Paris Agreement. On September 21, 2016, the documentation was handed over to the United Nations, transforming the country's intentions into official commitment.

Brazil's NDC has committed to reducing greenhouse gas emissions by $37 \%$ below 2005 levels by 2025 , with a subsequent reduction by $43 \%$ of the 2005 levels by 2030 . The country has committed to increase the share of sustainable bioenergy in its energy matrix to approximately $18 \%$ by 2030 , restore and reforest 12 million hectares of forests, and achieve an estimated $45 \%$ share of renewable energy in the composition of the energy matrix by 2030. 
Brazil's NDC corresponds to an estimated $66 \%$ reduction in greenhouse gas emissions per unit of GDP (emission intensity) by 2025 and $75 \%$ in terms of emission intensity by 2030 (both compared to 2005). Therefore, Brazil will reduce greenhouse gas emissions in the context of a continuous increase in population and GDP, as well as per capita income (data from the Brazilian Federal Government's Secretariat of the Environment). This initiative shows the success of Habermas' concept of deliberative citizenship. In much of the literature on this subject, authors use the Habermasian framework highlighting the author's Theory of Communicative Action. Deliberative citizenship "[...] means that the legitimacy of political decisions must originate in discussion processes guided by the principles of inclusion, pluralism, participatory equality, autonomy and the common good" (TENÓRIO, 2005, p. 105).

When it comes to Digital Economy, trust is critical. As Jean Tirole says,

Trust is important. There is the need for Internet users to have confidence in the digital ecosystem. This trust must apply at two levels: There is too much choice, too much information, too many people to interact with nowadays. Platforms are there to guide us and make up for our limited capacity to pay attention. This raises the question of the reliability of their recommendations. The second issue is the use made of personal data. This data is now a powerful economic and political asset for those who possess it. It will not always be used as we would wish, which raises the complex question of property rights over this data (TIROLE, 2017, p. 401).

When it comes to trust, concepts such as Charles Heckscher's 'post-bureaucratic organizations' or Mintzberg's 'adhocracy' propose that forms of work should be based on relationships of trust and the institutionalization of openness and dialogue.

One of the challenges Heckscher poses to organizations is developing the ability to mobilize people with a wide range of skills and visions to work together. In response to these challenges, the author makes some distinctions between key terms: he addresses the shift from bureaucratic system to the collaborative enterprise; points out essential dimensions of businesses such as strategies, structure, culture, and infrastructure. He proposes a transformational approach in which collaboration and interactive change-oriented leadership are essential, enabling outcomes that have the characteristic of modern times, i.e., focused on knowledge.

Heckscher (2007, p. 2-5) distinguishes the concepts around the idea of collaborative organizations, in which speed and synergy among stakeholders (various actors involved in a project or program) are crucial dimensions for knowledge-based or cooperation-based businesses:

- Cooperation takes place locally and among members. They are stable relationships, the organizations' boundaries are closed, and skills homogeneous;

- Extended collaboration occurs when relationships among members of the organization flow, and when they are in a process of change. Boundaries are more flexible and the skills and abilities of members are diverse. Teams, in this case, are often formed with contributors from outside the organization (such as business partners). Extended collaborations look more like a network, with a cluster that collaborates with their experiences and knowledge, creating synergy that leads to a superior outcome.

- Extended collaboration can be understood as the ability of individuals to work together beyond the scope of small groups.

Reinforcing the concept of collaboration, Heckscher (2007, p. 2-3) states:

Collaboration means "working together." This implies much more than "living together"; it involves a shared objective that cannot be reached without the contribution of all. Thus it necessarily implies processes of dialogue and negotiation, of exchanges of views and sharing of information, of building from individual views towards a shared consensus.

This open and collaborative dialogue among several nations was necessary when negotiating and signing the Paris Agreement, and, in companies, it is the type of conversation that allows exchange of information and cooperation for teamwork. It inspires 
the trust needed in innovation processes, institutionalizing the open and honest feedback, in more substantive communication. This is, for example, what General Electric intended to do in its organizational culture - as seen in the company's official position - at the time of Jack Welch - and intends to continue nowadays, reinforcing sustainable innovation. Institutionalizing such a culture is no simple task in organizations.

The articles in this issue deal with topics such as: business games and processes of collaboration and competition; network theory and social identity; autonomy and social justice in a civil organization in the Northeast Region of Brazil; the history of Latin America and the concept of citizenship; virtual community and identity; labor relations, identity, and career; limits on the use of police force; female managers and their careers with their children; sustainable innovation and entrepreneurship.

Article 1, "Adoption of business game under the perspective of an excellence model in an MBA course: multicriteria peer evaluation analysis," by Kaizô Iwakami Beltrão and Luiz Cesar Barçante, describes a business game applied in MBA programs as an activity of the last courses. The authors critically analyze the results of the game's implementation in 47 classes, involving 1,410 students. The business game aims to integrate the skills and competencies developed throughout the MBA program and uses a 39-item evaluation system based on a model of excellence that covers all important aspects of the management process.

Article 2, "Network theory of stakeholder influences: a revisited approach," by Fabricio Stocker, Keysa Manuela Cunha Mascena, Ana Cláudia Azevedo, João Maurício Gama Boaventura, shows that interactions with multiple stakeholders has gained importance in the last decades, due to rapid dissemination of information and the dynamic connections established among individuals and groups. The authors indicate that the topic deserves further empirical research analyzing stakeholder networks and their contribution to the advance of the theory studied.

Article 3, "Give a fish or teach to fish? Empowerment as a practice of social innovation in a civil society organization," by Thaís Teles Firmino and André Gustavo Carvalho Machado, analyzes empowerment as a practice of social innovation in a civil society organization in the Northeast Region of Brazil. The authors present an initiative empowering disadvantaged children and adolescents as an example of social innovation practice.

Article 4, "An essay on the history of citizenship in Latin America from a long-term perspective," by Luciano Enrique Andrenacci, presents an overview of the history of citizenship in Latin America.

Article 5, "Symbolic consumption and representation of self: a study of interactions in a virtual community of Ubuntu-Br users," by Osiris Luís da Cunha Fernandes, Nelson da Cruz Monteiro Fernandes, Fernando Gomes de Paiva Junior, André Luiz Maranhão de Souza Leão, and Marconi Freitas da Costa, explains how the symbolic consumption of the Ubuntu operating system is used to represent the self in interactions in the Brazilian Ubuntu virtual community.

Article 6, "Interdependence between networks and member firms in the evolution of inter-organizational networks," by Leander Luiz Klein and Breno Augusto Diniz Pereira, indicates that cooperation between companies in the form of networks can be considered a mechanism to obtain missing resources. They show that the resources provided by networks over time can become unique and result in dependence.

Article 7, "Young people's career choices based on employer branding," by Andrea Poleto Oltramari, Rosana Córdova, and Maria José Tonelli, critically discuss the importance of companies' branding in the career choice of young undergraduate students. The research is based on the current concepts of employer branding, consumption and lifestyle, prosumption and co-creation.

Article 8, "Meteor of illusions: The meaning of work for young public bank managers," by Elena Bandeira da Silva, Isabel de Sá Affonso da Costa, Jorge Augusto de Sá Brito and Freitas and Denise Medeiros Ribeiro Salles, presents results of a research on the meaning of work for young managers of public banks using the Theory of Social Representations. The approach is qualitative, descriptive, and interpretative.

Article 9, "Police use of deadly force in the State of São Paulo," by Samira Bueno, Renato Sérgio de Lima, and Marco Antônio Carvalho Teixeira, presents the police as the main mechanism of the modern state to ensure law and order, having as its prerogative the regulation of social relations through physical force as a legitimate and constitutive act of its function. 
Article 10, "Street-level bureaucrats' action in the implementation of public policies in Brazil: a proposal for expanded analysis," by Francesco Bonelli, Antonio Sérgio Araujo Fernandes, Denilson Bandeira Coêlho, and Jamili da Silva Palmeira, brings an analysis of the multiple dimensions of the street-level bureaucrats' performance in the implementation of public policies in Brazil. The study aims to contribute to a better understanding of the subject topic, based on an expanded analytical approach.

Article 11, "Deliberative citizenship and social management: a systematic literature review in Brazil," by Rafael Junior dos Santos Figueiredo Salgado, Luana Ferreira dos Santos, Tamiris Cristhina Resende, and Washington José de Souza, presents a systematic literature review of deliberative citizenship and social management. It analyzes how the concept of deliberative citizenship is applied in studies of social management in Brazil. The research used 'Capes' and 'Google Scholar' databases, adopting the descriptors "cidadania deliberativa" (deliberative citizenship) and "gestão social" (social management).

Article 12, "Building professional identity: a study with female managers who are baby boomers, generation Xers, and millennials," by Marlene Catarina de Oliveira Lopes Melo, Vilma Santos Pereira Faria, and Ana Lúcia Magri Lopes, analyzes the construction of professional identity of female managers from three generations: baby boomers, generation Xers and millennials. In methodological terms, this study adopted a qualitative-descriptive approach and interviewed 32 female managers in diverse sectors of the economy, located in the city of Belo Horizonte.

Article 13, “Uberization of labor and capitalist accumulation," by David Silva Franco and Deise Luiza da Silva Ferraz, is dedicated to the advancement of productive forces appropriated by capital, allied to the context of the transformation of socio-cultural relations that encompass the spheres of production and consumption. This has enabled the rise of the phenomenon of work 'uberization,' a term derived from the form of organization of the company Uber.

Article 14, "Entrepreneurship and identity politics: an analysis from the perspective of figuration sociology and critical social psychology," by Angelo Brigato Ésther, discusses identity by articulating elements of the critical perspective in social psychology - primarily through the syntagma 'identity-metamorphosis-emancipation' developed by Antônio Ciampa - as well as the concept of identity politics.

Article 15, "The construction of collective competencies in the dynamics of budgetary routines," by Samantha Luiza de Souza Broman, Roberto Lima Ruas, and Sandra Regina da Rocha-Pinto, demonstrates that the growing diffusion of collective work configurations in the current organizational environment has not been counterpart in the academic literature on the topic.

We wish you all a pleasant read!

PhD. Isabella F. Freitas Gouveia de Vasconcelos

PhD. Hélio ARThur REIS IRIgaray

EDITORS-IN-CHIEF 


\section{REFERENCES}

HECKSCHER, C. Google sites. [2019]. Available at: <https://sites. google.com/a/heckscher.us/charles-heckscher/>. Accessed on: Oct. 07, 2019.

HECKSCHER C.; DONNELLON, A. The post-bureaucratic organization. Thousands Oaks: Sage, 1994.

HECKSCHER, C. The Collaborative Enterprise. New Haven: Yale University Press, 2007.
TENORIO, F. Tem Razão a Administração? Ensaios de teoria organizazional. 3. ed. Ijuí: Ed. Unijui, 2008. (Coleção Administração e Contabilidade).

TIROLE, J. Economics for the Common Good. Princeton: Princeton University Press, 2017.

WELCH, J. Paixão Por Vencer - A Bíblia do Sucesso. São Paulo: Campus Elsevier, 2005.

Profa. Dra. Isabella Francisca Freitas Gouveia de Vasconcelos

ORCID: https://orcid.org/0000-0001-9109-0475

Doctorat es Sciences de Gestion / HEC - Ecole des Hautes Etudes Commerciales, France (2000); PhD in Human Resource Administration from FGV EAESP (1997), Brazil; Post-Doctorate from Rutgers, The New Jersey State University, USA; Adjunct Professor at FGV EBAPE, Brazil; Researcher at CNAMConservatoire National D’Arts et Metiers, France. E-mail: isabella.vasconcelos@fgv.br

Prof. Dr. Hélio Arthur Reis Irigaray

ORCID: https://orcid.org/0000-0001-9580-7859

PhD in Business Administration from FGV EAESP; Masters in Business Administration from PUC-Rio and Bachelor Degree in Economics from the University of Northern lowa, USA. Assistant Professor at FGV EBAPE and at the Corporate International Masters (CIM) program of the Georgetown University, Washington, USA. Leader researcher on the theme Diversity and Labor Relations, in the area of Work Management of the National Association of Graduate Studies and Research in Administration (ANPAD). E-mail: helio.irigaray@fgv.br 